\title{
Job Characteristics' Causal Effects on Individual Job Performance Perceptions and Mediating Role of Job Satisfaction
}

\author{
Metin KAYA ${ }^{*}$, Halil DEMIRER ${ }^{* *}$
}

Received: July 12, 2021. Revised: November 30, 2021. Accepted: December 6, 2021

\begin{abstract}
This study aims to reveal the dimensions of job characteristics' causal effects on the dimensions of job performance perception and the mediating role of extrinsic and intrinsic job satisfaction in this relationship. All the variables are examined for individual-organization interaction at the individual level.

Primary research data were gathered by using a structured questionnaire that included valid and reliable scales, namely Job Characteristics Inventory, Minnesota Job Satisfaction Questionnaire, and The Job performance quality scale. The sample of the study consists of 472 employees randomly chosen from five private and public hospitals in Turkey. Exploratory and confirmatory factor analyses are used for factor validation. Path analysis and bootstrap analyses are used to detect direct and mediating effects on a path model using the structural equation modeling technique. Findings revealed that skill variety and friendship have a positive causal effect on compliance and task performance. Friendship, skill variety, and autonomy have a positive causal effect on job satisfaction. Internal job satisfaction has a positive causal influence on compliance, contextual, and task performance. Friendship, skill variety, and autonomy's causal effects on compliance, contextual, and task performance are mediated by intrinsic and extrinsic job satisfaction.
\end{abstract}

Keywords: Job Characteristics, Job Performance, Intrinsic Job Satisfaction, Extrinsic Job Satisfaction, Health Workers

JEL Classification Codes : M12, J28, C83, D23

UDC : 331.44

DOI : https://doi.org/10.17015/ejbe.2021.028.04.

\footnotetext{
${ }^{*}$ Assistant Professor, Logistics Program, İstanbul Esenyurt University, Turkey. E-mail: metinkaya98@ttmail.com

** Professor, Visiting lecturer HMKW, Germany. E-mail: halildemirer1@gmail.com

Copyright (C), 2021 Ala-Too International University.
} 


\section{Introduction}

In early studies of job design and work engagement, the need for previous empirical pieces of evidence to test the job characteristics' causal effects on individual work behavior is emphasized (Hackman \& Lawler, 1971). But, in the following research history, core and interpersonal job characteristics such as job identity, autonomy, skill variety, feedback, cooperation, and friendship have been separately investigated for the correlations with job performance and job satisfaction in various empirical studies that stemmed from Job Characteristics school. Even though some researchers indicated the need for more empirical research testing the job characteristics' effects on performance perception and the mediating role of job satisfaction is required (Fried \& Ferris, 1987; Loher et al., 1985; Wegman et al., 2018), there found only a few studies on job characteristics' direct determination on job satisfaction and job performance and the mediation effect of job satisfaction on the relationship between job characteristics and job performance perception in Wegman et al.'s (2018) meta-analysis.

This study is designed to fill this gap in the literature by testing the direct causal effects of job characteristics on job performance. Moreover, although satisfaction and performance relationship research history goes back to the rise of industrialorganizational psychology (Roznowski \& Hulin, 1992), it should still be considered as a research area due to unceasing changes in the compositions of characteristics of jobs in today's organizations. So, the mediation of job satisfaction in the relationship between job characteristics and job performance perception is also tested in this study.

In the findings of this study, it is expected to find some more evidence that contributed to the causal relationships among job characteristics, job satisfaction, and job performance. Two main research questions are formulated as "Do job characteristics' deter-mine job performance perceptions?" and "Are job characteristics' determinations on job performance perceptions mediated by job satisfaction?" As the majority of the empirical studies examining job characteristics' effects on job performance evaluations are in the field of health organization workforce, to make contributions to the job performance evaluation problems among health industry workers, the empirical findings of research in health organizations are used for comparisons.

\section{Literature Review}

\subsection{Job characteristics' influence on job performance}

The job characteristics model illustrates a work redesign in which characteristics of enriched jobs are tested to lead to positive performance outcomes (Hackman \& Oldham, 1976). In an integrative work design approach, job characteristics are listed in de-tail under four groups: task (task identity, task significance, feedback, autonomy), knowledge (job complexity, skill variety), social (interdependence, feedback from 
Job Characteristics' Causal Effects on Individual Job Performance Perceptions...

others, support from society) physical (work conditions, ergonomics, workload), and additional (workday cycles, time pressure) job characteristics (Grant et al., 2009). The importance of the dimensions of the job characteristics model is subject to change as well (Oldham \& Hackman, 2010). Among many of the job characteristics scales in the literature, six dimensions as friendship, skill variety, autonomy, feedback, work identity, and cooperation are found to be mostly measured (Sims et al., 1976).

Friendship is the level of ability to build informal relationships and friendships at the job. It is a sort of social support that decreases turnover intentions while increasing job satisfaction, organizational commitment (Hackman \& Lawler, 1971; Morgeson \& Humphrey, 2008). Skill variety is the level of number and variety of activities and talents of the job required. It may bring about meaningfulness to work, work motivation, satisfaction and, involvement at work. But it may also have reverse returns such as high compensation expectations (Morgeson \& Humphrey, 2008). Autonomous work groups and job enrichment are two popular attempts for skill variety in jobs (Parker and Wall, 1998). Autonomy is the level of work-related discretion, and freedom workers can get in how to do their job in terms of methods and scheduling. Anxiety, stress, ambiguity, burnout, and conflicts at work could be reduced by giving more autonomy to employees. It may bring about job satisfaction, organizational commitment, and work motivation (Morgeson \& Humphrey, 2008; Park \& Searcy, 2012). Feedback is the level of information a worker can get about his performance on the job (Humphrey et al., 2007). Identity of work is the clarity and uniqueness level of a job assignment which means that work with identity should be permanently observable, identifiable, and sustainable. The work is a whole made up of meaningful pieces (Grant et al., 2009). Cooperation is the degree to which a job requires employees to deal with other people to complete the work (Sims et al., 1976).

Individual work performance is measurable employee behaviors that contribute to organizational goals (Viswesvaran \& Ones, 2000). Thus, individual work performance is a latent construct made up of multiple dimensions that can be measured by the indicators of these dimensions (Viswesvaran, 2002). These dimensions are task performance, compliance performance, contextual performance, and counterproductive behavior at work (Koopmans et al., 2011).

Task performance as the traditional focus of the performance is the proficiency in the performance of the central job tasks. Completing job tasks and work quantity and job skills are some of its indicators. In-role performance, technical proficiency, and job knowledge are used to express task performance (Koopmans et al., 2011; Viswesvaran et al., 2002). Compliance performance refers to the employee's adaptability to change levels in a working system or work roles. Creative problemsolving, adapting to new people and new surroundings, dealing with uncertainty and, learning new tasks are some of its indicators. It is closely related to the openness to change and coping with change (Koopmans et al., 2011). Contextual performance is not directly related to technical and core job behaviors. It is related to the behaviors 
that support the social, psychological, and organizational environment of the job. Some of its indicators are enthusiasm, attention to duty, resourcefulness, and industriousness. It is closely related to interpersonal relations, extra-role performance, and citizenship behavior (Koopmans et al., 2011). The behaviors that harm the well-being of the organization are called counterproductive work behavior. Absenteeism, destructive and hazardous behaviors, off-task behaviors, and aggression are some of its indicators (Koopmans et al., 2011; Murphy, 1989).

There are empirical findings from various cultures that the job characteristics of the employees directly influence their job performance (Judge et al., 2001). In an early study that used measurement tools from Hackman and Oldham (1976) and Churchill et al. (1979), Tyagi (1985) found that U.S. insurance salespersons' skills variety $(\beta=0.39, p<0.01)$ and autonomy $(\beta=0.38, p<0.01)$ have direct effects on their job performance. Singh (1998), using measurement tools from Hackman and Oldham (1976) and Dubinsky and Mattson (1979), found that in U.S. salespersons, skills variety has a direct effect on their job performance $(\beta=0.21, p<0.01)$. Trépanier et al. (2015), using measurement tools from Van de Ven et al. (2008) and Williams and Anderson (1991), found that Canadian nurses' autonomy has a direct effect on their job performance $(\beta=0.26, p<0.01)$. Johari and Yahya (2016), using measurement tools from Hackman and Oldham (1975), Williams and Anderson (1991), Van Dyne and Le Pine (1998), and Podsakoff et al. (1990), found that Malaysian supervisors' skills variety has a direct effect on their job performance $(\beta=0.67, p<0.05)$. Millette and Gagné (2008), using measurement tools from Hackman and Oldham (1976), found that U.S. health workers' skills variety $(\beta=0.21, p<0.05)$ and autonomy $(\beta=0.25$, $p<0.01$ ) have a direct effect on their job performance. Chu and Lai (2011), using measurement tools from Hackman and Oldham (1976), found that Taiwanese accountants' autonomy has a direct effect on their job performance in terms of problem-solving $(\beta=0.35, p<0.001)$ and innovativeness $(\beta=0.08, p<0.01)$. Peiró et al. (2020), using measurement tools from Morgeson and Humphrey (2008) and Abramis (1994), found that Colombian employees' autonomy $(\beta=0.17, p<0.01)$ and skills variety $(\beta=0.17, p<0.01)$ have a direct effect on their job performance. Based on the evidence given above, job characteristics are expected to have a positive causal effect on job performance, and the following hypotheses are suggested:

H1. Skill variety has a significant positive influence on job performance.

H2. Autonomy has a significant positive influence on job performance.

H3. Friendship has a significant positive influence on job performance.

\subsection{Job characteristics' influence on job satisfaction}

Job satisfaction is one's emotional or affective response to various job facets (Kinicki \& Fugate, 2016). Intrinsic Job Satisfaction is the extent to having a sense of achievement and having the chance to use abilities at the job (Fields, 2002). Extrinsic 
Job Characteristics' Causal Effects on Individual Job Performance Perceptions...

Job Satisfaction is satisfaction with chances for progress at work, pay, and recognition (Judge et al., 2001).

There are empirical findings that the job characteristics have a direct causal effect on job satisfaction in both western and non-western cultures. Jansen et al. (1996), using measurement tools from Algera et al. (1986) and Boumans (1990), found that Netherlander nurses' skills variety $(\beta=0.21, p<0.01)$ has a direct effect on their job satisfaction. Singh (1998), using measurement tools from Hackman and Oldham (1976) and Jansen et al. (1996), found that U.S. salespersons' autonomy has a direct effect on their job satisfaction $(\beta=0.17, p<0.01)$. Van den Berg and Feij (2003), using measurement tools from Taber and Taylor (1990) and Hackman and Old-ham (1975), found that U.S. job applicants' autonomy $(\beta=0.39, p<0.01)$ and skills variety $(\beta=0.21$, $p<0.01$ ) have a direct effect on their job satisfaction. Namm (2003), using measurement tools from Hackman and Oldham (1980) and Hackman and Oldham (1975), found that U.S. employees' skills variety has a direct effect on their job satisfaction $(\beta=0.17, p<0.01)$. Dore (2004), using measurement tools from Hackman and Oldham (1975) and Idaszak and Drasgow (1987), found that US IT professionals' autonomy $(\beta=0.16, p<0.05)$ and skills variety $(\beta=0.13, p<0.05)$ have a direct effect on their job satisfaction. Millette and Gagné (2008), using measurement tools from Hackman and Oldham (1975), found that U.S. volunteer servants' autonomy $(\beta=0.35$, $p<0.001)$ and skills variety $(\beta=0.27, p<0.01)$ have a direct effect on their job satisfaction. Ford and Wooldridge (2012) found that U.S. service workers' autonomy $(\beta=0.51, p<0.01)$ and skills variety $(\beta=0.71, p<0.01)$ have a direct effect on their job satisfaction. Ali et al. (2014), using measurement tools from Hackman and Oldham (1974), found that Malaysian restaurant managers' autonomy $(\beta=0.44, p<0.001)$ and skills variety $(\beta=0.21, p<0.05)$ have a direct effect on their job satisfaction. Riasudeen and Venkatesakumar (2014), using measurement tools from Hackman and Lawler (1971) and MacDonald and Intyre (1997), found that Indian service employees' autonomy $(\beta=0.60, p<0.01)$ and skills variety $(\beta=0.41, p<0.05)$ have a direct effect on their job satisfaction. Giles et al. (2017), using measurement tools from Guest et al. (2001), found that Australian nurse consultants' autonomy has a direct effect on their job satisfaction $(\beta=0.22, p<0.05)$. Garcia et al. (2019), using measurement tools from Morgeson and Humprey (2008) and Cooper et al. (1989), found that Spanish workers' autonomy has a direct effect on their internal $(\beta=0.44, p<0.01)$ and external $(\beta=0.18, p<0.01)$ job satisfaction. Based on the empirical evidence, job characteristics are expected to have a positive causal effect on job satisfaction, and the hypotheses below are proposed:

H4. Autonomy has a significant positive influence on job satisfaction.

H5. Skill variety has a significant positive influence on job satisfaction.

H6. Friendship has a significant positive influence on job satisfaction. 


\subsection{Job satisfaction's influence on job performance}

Job satisfaction positively influences individual job performance perception (Judge et al., 2001), and there is empirical evidence about job satisfaction's causal effect on job performance in both western and non-western cultures. Keaweney and Nelson (1993) found that U.S. marketing personnel's job satisfaction has a direct effect on their job performance perception ( $\beta=0.29, p<0.001$ ). Gül et al. (2008), using MSQ as a measurement tool, found that Turkish health workers' job satisfaction has a direct effect on their job performance perception $(\beta=0.39, p<0.01)$. Funmilola et al. (2013) found that Nigerian SME employees' external job satisfaction has a direct effect on their job performance perception $(\beta=0.39, p<0.05)$. Perera et al. (2014), using the measurement tools from Weiss et al. (1967) and Cox and Nkomo (1986), found that Sinhalese factory employees' job satisfaction has a direct effect on their job performance perception $(\beta=0.67, p<0.001)$. Al (2016), using measurement tools from Bakan and Büyükbeşe (2004) and Choo (1986), found that Turkish salespersons' job satisfaction has a direct effect on their job performance perception $(\beta=0.55, p<$ 0.001). Topcu et al. (2017), using measurement tools from Judge et al. (2001) and Sigler and Pearson (2000), found that Turkish employees' job satisfaction has a direct effect on their job performance perception $(\beta=0.42, p<0.001)$. Yustina and Valerina (2018), using measurement tools from Hartline and Ferrel (1996) and Jones et al. (2010), found that Indonesian accountants' job satisfaction has a direct effect on their job performance perception ( $\beta=0.60, p<0.01$ ). Shafique et al. (2018), using measurement tools from Bell et al. (2012) and Lynch et al. (1999), found that Pakistani tourism employees' job satisfaction has a direct effect on their job performance perception $(\beta=0.71, p<0.001)$. Marbawi et al. (2018), using a measurement tool from Siahaan (2018), found that Indonesian bank employees' job satisfaction has a direct effect on their job performance perception $(\beta=0.23, p<0.01)$. Riyadi (2019), using the measurement tool Simamora (1997), found that East Borneon manufacturing employees' job satisfaction has a direct effect on their job performance perception $(\beta=0.25, p<0.05)$. Idris et al. (2020), using measurement tools from Mabaso and Dlamini (2017) and Jamil and Raja (2011), found that Indonesian civil servants' job satisfaction has a direct effect on their job performance perception $(\beta=0.76, p<0.05)$. Astuti et al. (2020), using a hybrid measurement tool, found that Indonesian civil servants' job satisfaction has a direct effect on their job performance perception $(\beta=0.68, p<0.01)$. Edward and Kaban (2020) found that Indonesian shipyard employees' job satisfaction has a direct effect on their job performance perception $(\beta=0.27, p<0.01)$. Mardanov (2020), using measurement tools from Scarpello and Campbell (1983) and Marques-Quinteiro and Curral (2012), found that Taiwanese construction employees' job satisfaction has a direct effect on their job performance perception $(\beta=0.25, p<0.001)$. Dinc and Plakalovic (2016) found that there is an indirect relationship between overall job satisfaction and job performance of bank employees through a mediating role of affective commitment in Bosnia and Herzegovina. Based on the empirical evidence given above, job 
Job Characteristics' Causal Effects on Individual Job Performance Perceptions...

satisfaction is expected to have a positive causal effect on job performance, and the following hypothesis is suggested:

H7. Job satisfaction has a significant positive influence on job performance.

\subsection{Job satisfaction's mediating effect in the relationship between job characteristics and job performance}

In the study with civil servants in Indonesia, (Idris et al., 2020) reported that the work environment's influence on job performance is positively mediated by job satisfaction $(\beta=0.26, p<0.05)$. In the other study in Indonesia, it is reported that job satisfaction mediated family-work conflicts $(\beta=0.42, \quad p<0.05)$ and work-family conflicts $(\beta=0.42, p<0.05)$ (Yustina \& Valerina, 2018). In research with the Indonesian sample, job satisfaction is found to have a mediating effect on the personal competencies effect of job performance perception (Edward \& Kaban, 2020). Based on the scarce empirical evidence given above and the modern job design approach (Grant et al., 2009), the hypothesis below is proposed as internal job satisfaction needed to be tested for a mediating effect in the relationship between job characteristics and job performance:

H8. Job characteristics' influence on job performance is positively mediated by internal job satisfaction.

The research model draws on the job characteristics and relational job theories stating that job characteristics constitute the internal motivating aspect of the work. As employees see that their work has significant effects on others, they attribute more meaning to work and thus have a high internal motivation (Hackman \& Oldham, 1974). So, the first argument in the model is that job characteristics positively influence job performance perception. The next argument is the job satisfaction's mediating effect that increases the strength of the effect in this relationship. The conceptual research model examined in this study is shown in Figure 1.

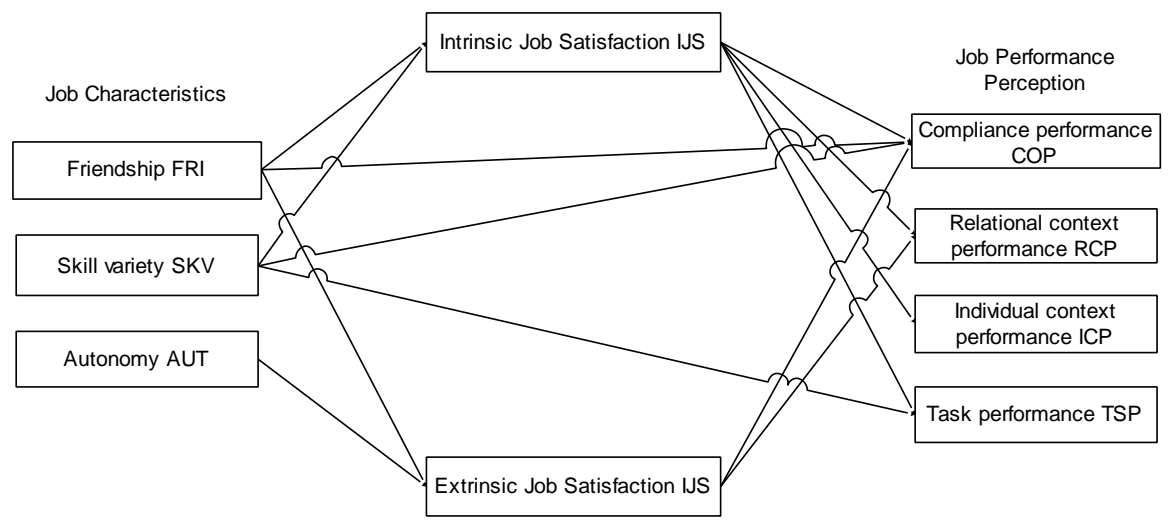

Figure 1. Primary Research Model 
In the primary research model, friendship, skill variety, autonomy, feedback, work identity, and cooperation with others were exogenous latent variables. Work identity and cooperation are dropped in the analysis. Internal and external job satisfaction was the endogenous latent variables that were placed as mediators. Compliance performance, relational context performance, individual context performance, task performance, and counterwork performance were latent dependent variables. Counterwork performance is dropped in the analysis. Gender, level of education, marital status, position, and income levels of participants were placed to control the primary model.

\section{Methods}

\subsection{Statistical analysis}

The scope of the research is limited to employees, and the research variables are examined at the organization-individual interaction level by analyzing primary data gathered by a structured questionnaire. In the process of analysis, first, the normal distribution assumptions are tested. Then, the factor structures of all research scales are tested by using exploratory and confirmatory factor analyzes with internal reliability analysis in the Turkish sample. The direct effect hypotheses are tested with the regression coefficients on the final path model in AMOS and, the indirect effect hypotheses are tested by a bootstrapping plugin (Gaskin \& Lim, 2018).

\subsection{Sampling and procedure}

The minimum sample size required for the path model was calculated as 184 by using the A-priori sample size calculator (Soper, 2021). In the formula, 0.1 entered for the expected size of the effect, 0.8 for the statistical power level desired, 0.05 for the level of probability, 17 for the number of latent variables and, 100 for the number of observable variables (Westland, 2010). The participants were chosen on a simple random basis from three private and two public hospitals in five different cities that allowed survey execution in 2018 in Turkey. The hospitals in the research sample have an average of 696 employees and ten years of activity in the field. The employees voluntarily participated in the survey. The actual sample size was 472 hospital employees, which meets the number needed for confirmatory factor analyses as well (Boomsma, 1982).

\subsection{Measures}

Demographic questions and Likert-type scales with 6-point valued 97 reflective statements are used for measurement in the survey. Calculations are made by having averages.

Job characteristics scale: A Turkish adaptation of the 30-item Job Characteristics Inventory is used to measure job characteristics (Sert, 2017; Sims et al., 1976). The scale has six dimensions as friendship, skill variety, autonomy, feedback, work identity, and cooperation which are similar to dimensions in The Job Diagnosis Scale 
Job Characteristics' Causal Effects on Individual Job Performance Perceptions...

(Hackman \& Oldham, 1974). The internal consistency reported for the scale varied between $(\alpha=0.62)$ and $(\alpha=0.84)$ in a health organization (Sims et al., 1976).

Job satisfaction scale: A Turkish adaptation of the 20-item short-form MJSQ is used to measure job satisfaction (Fields, 2002; Yaldızbaş, 2015). Two dimensions in the scale are intrinsic job satisfaction $(\alpha=0.85)$ and extrinsic job satisfaction $(\alpha=0.91)$.

Job performance scale: A Turkish adaptation of 47-item The JPQ scale is used to measure job performance perception (Aslan, 2017; Koopmans et al., 2011). The selfrating measure had four factors with satisfactory reliability values [task performance $(\alpha=0.93)$, context performance $(\alpha=0.91)$, compliance performance ( $\alpha=0.93)$ and counterproductive work behavior $(\alpha=0.81)$ ]. Calculations for counterproductive work behavior were made after reversing the scores (Koopmans et al., 2011).

\subsection{Data gathering and normality}

Research data is gathered by pen and paper questionnaires with the help of an interviewer who has a general idea about the research. The data set included 472 participants and 97 statements, and five demographic variables. First, all the reverse encoded variables have been corrected. All participants and variables preserved their place in the data set as the number of missing values did not exceed $10 \%$, both based on participants and variables which were filled by the mean for continuous variables and the median for discrete variables. Skewness and kurtosis calculations are made with absolute values as the sample size is larger than 300 (West et al., 1995).

The responses for all scales were normally distributed, with skewness values between -1 and $+1(\mathrm{SE}=0,11)$ and kurtosis values between -3 and $+3(\mathrm{SE}=0,22)$ (West et al., 1995). There were no outliers and influential values beyond these thresholds. There were no multicollinearity problems (VIF $<3$ ) among measurement variables in the equation either (Hair et al., 2010)

\section{Results}

\subsection{Descriptive findings}

The descriptive information about survey participants and their organizational information is presented in Table 1.

\section{Table 1. Participants' information}

\begin{tabular}{llll}
\hline Variable & & Account & Ratio \\
\hline \multirow{2}{*}{ Gender } & Female & 321 & $68.0 \%$ \\
\cline { 2 - 4 } & Male & 151 & $32.0 \%$ \\
\hline \multirow{2}{*}{ Educatal status } & Married & 194 & $41.1 \%$ \\
\cline { 2 - 4 } & Non-married & 278 & $58.9 \%$ \\
\hline & Elementary & 20 & $4.2 \%$ \\
\cline { 2 - 4 } & High school & 165 & $35.0 \%$ \\
\cline { 2 - 4 } & College & 155 & $32.8 \%$ \\
\hline
\end{tabular}




\begin{tabular}{llll}
\hline & Undergraduate school & 107 & $22.7 \%$ \\
\cline { 2 - 4 } & Graduate school & 25 & $5.3 \%$ \\
\hline \multirow{2}{*}{ Position } & Manager & 113 & $23.9 \%$ \\
\cline { 2 - 4 } & Employee & 359 & $76.1 \%$ \\
\hline \multirow{2}{*}{ Income level } & Expenses exceed income & 48 & $10.2 \%$ \\
\cline { 2 - 4 } & Equilibrium & 181 & $38.3 \%$ \\
\cline { 2 - 4 } & Income exceeds expenses & 243 & $51.5 \%$ \\
\hline Hospitals & Private & 273 & $57.8 \%$ \\
\cline { 2 - 4 } & Public & 199 & $42.2 \%$ \\
\hline
\end{tabular}

\subsection{Exploratory factor analyses}

The factorial structure of survey scales is explored in the Turkish sample; the items of the instruments were exposed to exploratory factor analysis (Netemeyer et al., 2003). MLS (eigenvalue=1) and Promax-kappa 4 rotation methods were preferred as the method of inference for all scales. The factor structure is based on MLS covariance matrices. Items that have no cross-loading in the final pattern matrix under a certain number of factors indicated discriminant validity. The items had values greater than 0.3 in a factor, and the average value is greater than 0.5 for each factor indicated convergent validity.

Job characteristics: The 30-item instrument used for measuring job characteristics was subjected to exploratory factor analysis. The adequacy of sampling for the analysis was satisfactory (KMO=0.94), BTS X2 (210) $=5552.97, \mathrm{p}<0.001$. The MLS factor analysis with a cutoff point of 0.47 and Kaiser's criterion of eigenvalues greater than 1 produced a three-factor solution as the best fit for the data, accounting for $59 \%$ of the variance (Field, 2002). As presented in Table 2, the final scale had internally consistent 21 items (Bowling, 2002; Loewenthal, 2004). EFA produced a three-factor solution which is different from the original scale with a six-factor structure as feedback, work identity, and cooperation factors are dropped due to insufficient factor loadings (Sims et al., 1976). This is found as a parsimonious solution, given that exploring fewer factors contributes to parsimony (Gibson et al., 2020). But at the same time, it suggested that the participants in our sample perceived the statements in the job characteristics scale as slightly different from the previous studies (Field, 2002).

Job satisfaction: The 20-item job satisfaction instrument was subjected to exploratory factor analysis. The sampling adequacy for the analysis was satisfactory $(\mathrm{KMO}=0.93)$, BTS X2 $(75)=3,474.29, \mathrm{p}<0.001$. The MLS factor analysis with a cutoff point of 0.56 and Kaiser's criterion of eigenvalues greater than 1 offered a solution with two factors as the best fit for the data, accounting for $63 \%$ of the variance (Field, 2002). There were internally consistent 13 items (Bowling, 2002; Loewenthal, 2004) under the factors internal and external job satisfaction in the final scale (Table 3 ). The factor solution was quite similar to the two-factor original study suggesting that the participants in our sample perceived the structure of job satisfaction quite similar to the previous studies (Field, 2002; Sims et al., 1976). 
Job Characteristics' Causal Effects on Individual Job Performance Perceptions...

Table 2. Job characteristics pattern matrix

\begin{tabular}{|c|c|c|c|}
\hline \multirow[t]{2}{*}{ Items } & \multicolumn{3}{|c|}{ Factors } \\
\hline & FRI $\alpha=0.94$ & SKV $\alpha=0.78$ & AUT $\alpha=0.72$ \\
\hline isk21 & 0.779 & & \\
\hline isk24 & 0.757 & & \\
\hline isk25 & 0.753 & & \\
\hline isk29 & 0.748 & & \\
\hline isk28 & 0.748 & & \\
\hline isk16 & 0.727 & & \\
\hline isk26 & 0.684 & & \\
\hline isk27 & 0.684 & & \\
\hline isk20 & 0.671 & & \\
\hline isk22 & 0.669 & & \\
\hline isk17 & 0.658 & & \\
\hline isk15 & 0.644 & & \\
\hline isk23 & 0.644 & & \\
\hline Isk 6 & & 0.668 & \\
\hline Isk 7 & & 0.653 & \\
\hline Isk 3 & & 0.636 & \\
\hline Isk 1 & & 0.479 & \\
\hline isk11 & & 0.470 & \\
\hline Isk 8 & & & 0.667 \\
\hline isk10 & & & 0.569 \\
\hline isk13 & & & 0.490 \\
\hline
\end{tabular}

Extraction Method: Maximum Likelihood. Rotation Method: Promax with Kaiser Normalization. Rotation converged in 8 iterations. (isk: job characteristics)

Table 3. Job satisfaction pattern matrix

\begin{tabular}{ccc}
\hline Items & \multicolumn{2}{c}{ Factors } \\
\cline { 2 - 3 } & IJS $\alpha=0.89$ & EJS $\alpha=0.88$ \\
\hline it2 & 0.793 & \\
\hline it6 & 0.767 & \\
\hline it9 & 0.747 & \\
\hline it5 & 0.736 & \\
\hline it7 & 0.723 & 0.827 \\
\hline it4 & 0.599 & 0.820 \\
\hline it10 & 0.581 & 0.730 \\
\hline it15 & & 0.726 \\
\hline it14 & & 0.667 \\
\hline it17 & & 0.556 \\
\hline it13 & & \\
\hline it16 & & \\
\hline it19 & & \\
\hline
\end{tabular}

Extraction Method: Maximum Likelihood. Rotation Method: Promax with Kaiser Normalization. Rotation converged in 3 iterations. (it: job satisfaction) 
Job performance: The 47-item job performance instrument was subjected to exploratory factor analysis. The adequacy of sampling for the analysis was satisfactory $(K M O=0.95), B T S \times 2(435)=10,834.49, p<0.001$. The MLS factor analysis with a cutoff point of 0.48 and Kaiser's criterion of eigenvalues greater than 1 produced a solution surprisingly with one more factor having internally consistent 30 items (Loewenthal, 2004) (Table 4).

\section{Table 4. Job performance perception pattern matrix}

\begin{tabular}{|c|c|c|c|c|c|}
\hline \multirow[t]{2}{*}{ Items } & \multicolumn{3}{|c|}{ Factors } & \multirow[b]{2}{*}{ ICP $\alpha=0.90$} & \multirow[b]{2}{*}{$\operatorname{TSP} \alpha=0.76$} \\
\hline & CPW $\alpha=0.95$ & $\operatorname{COP} \alpha=0.92$ & $\mathrm{RCP} \alpha=0.91$ & & \\
\hline$z v d 4 r$ & 0.909 & & & & \\
\hline $\mathrm{zvd} 3 \mathrm{r}$ & 0.887 & & & & \\
\hline $\mathrm{zvd2r}$ & 0.871 & & & & \\
\hline$z v d 5 r$ & 0.863 & & & & \\
\hline$z v d 6 r$ & 0.860 & & & & \\
\hline$z v d 7 r$ & 0.846 & & & & \\
\hline $\mathrm{zvd} 1 \mathrm{r}$ & 0.750 & & & & \\
\hline up5 & & 0.898 & & & \\
\hline up7 & & 0.844 & & & \\
\hline up3 & & 0.800 & & & \\
\hline up6 & & 0.755 & & & \\
\hline up8 & & 0.722 & & & \\
\hline up2 & & 0.628 & & & \\
\hline up4 & & 0.612 & & & \\
\hline up1 & & 0.497 & & & \\
\hline ip11 & & & 0.867 & & \\
\hline ip9 & & & 0.842 & & \\
\hline ip10 & & & 0.737 & & \\
\hline ip8 & & & 0.674 & & \\
\hline ip12 & & & 0.669 & & \\
\hline ip14 & & & 0.568 & & \\
\hline ip13 & & & 0.519 & & \\
\hline ip5 & & & & 0.846 & \\
\hline ip4 & & & & 0.737 & \\
\hline ip3 & & & & 0.675 & \\
\hline ip2 & & & & 0.645 & \\
\hline ip6 & & & & 0.629 & \\
\hline gp2 & & & & & 0.967 \\
\hline gp1 & & & & & 0.575 \\
\hline gp5 & & & & & 0.477 \\
\hline
\end{tabular}

Extraction Method: Maximum Likelihood. Rotation Method: Promax with Kaiser Normalization.

Rotation converged in 6 iterations. (zvd: counterproductive work behavior, up: compliance performance, ip: relational performance, gp: task performance)

The factor solution was different from the four-factor original study (Koopmans et al., 2011). The context performance appeared to be in two categories which are named relational context performance and individual context performance, as items 
Job Characteristics' Causal Effects on Individual Job Performance Perceptions...

were grouped into two categories. All the five factors responsible for $70 \%$ of the variance best fit the data. This suggested that the participants in our sample perceived the structure of job performance as slightly different from the previous studies, which may be due to translation and cultural differences among samples (Field, 2002).

\subsection{Measurement models}

The models that arose in the exploratory factor analyses were then examined by using confirmatory factor analyses for validity considerations. In the process of obtaining goodness of fit in measurement models, measurement model incompatibilities are eliminated in two ways. First, incompatible observed variables that are considered to be connected with another latent variable are removed from the scales. Second, covariance assignments are made among error values of observed variables within the same latent variable. Model fit attained regarding thresholds (Bollen \& Lennox, 1991; Browne \& Cudeck, 1992; Hair et al., 2010; R. Hoyle, 1995; Jöreskog \& Sörbom, 1989; Kline, 2015; MacCallum et al., 1996; Pedhazur, 1997).

Job characteristics: Three latent and 17 observed variables remained in the final job characteristics measurement model after dropping four observed variables (Figure 2).

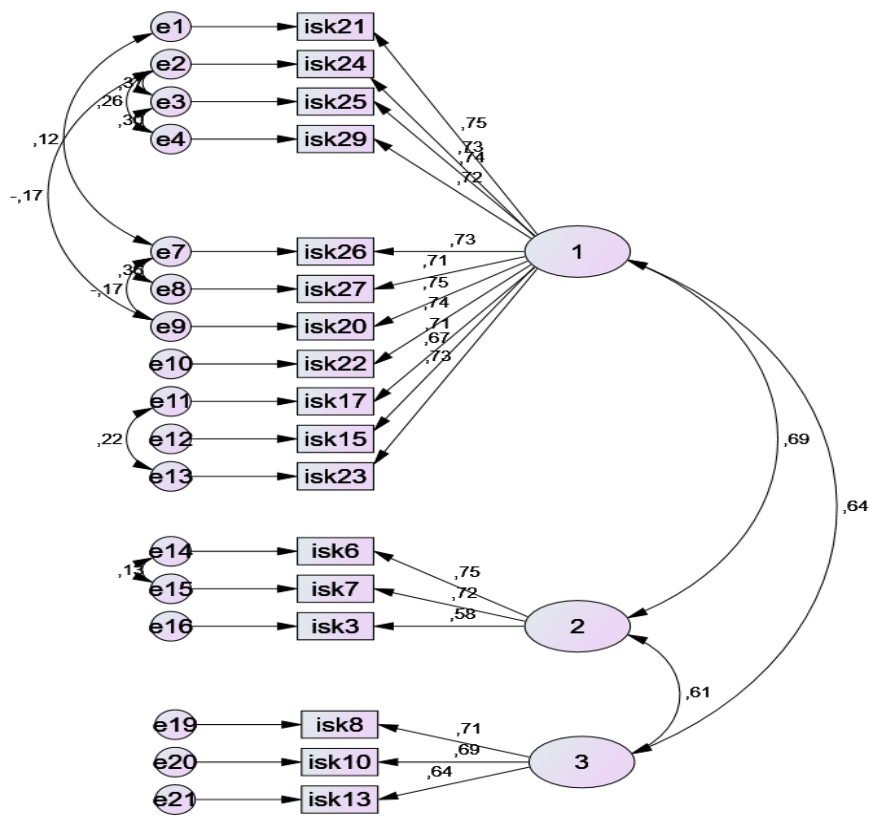

(CMIN/DF 2,743; SRMR 0,041; GFI 0,933; RMSEA 0,061; TLI 0,943; CFI 0,955)

Figure 2. Job characteristics measurement model 
The latent variables are named friendship (1), skill variety (2), and autonomy (3). The results of job characteristics measurement model validity analyses in Table 5 are satisfactory (Hu \& Bentler, 1999).

\section{Table 5. Validity analyses of job characteristics}

\begin{tabular}{cccccccc}
\hline & CR & AVE & MSV & MaxR(H) & $\mathbf{1}$ & $\mathbf{2}$ & $\mathbf{3}$ \\
\hline 1 FRI & 0.925 & 0.528 & 0.474 & 0.925 & 0.727 & & \\
\hline 2 SKV & 0.726 & 0.471 & 0.474 & 0.740 & $0.688^{* * *}$ & 0.686 & \\
\hline 3 AUT & 0.723 & 0.466 & 0.415 & 0.726 & $0.645^{* * *}$ & $0.607^{* * *}$ & 0.683 \\
\hline
\end{tabular}

Reliability $(C R>0,7)$, Convergent validity $(A V E>0,5)$, (CR $>A V E)$, Discriminant validity $(M S V<A V E)$, Partly discriminant validity (ASV>inter-factor correlations)

Job satisfaction: The latent and observed variables remained unchanged in the final job satisfaction measurement model (Figure 3).

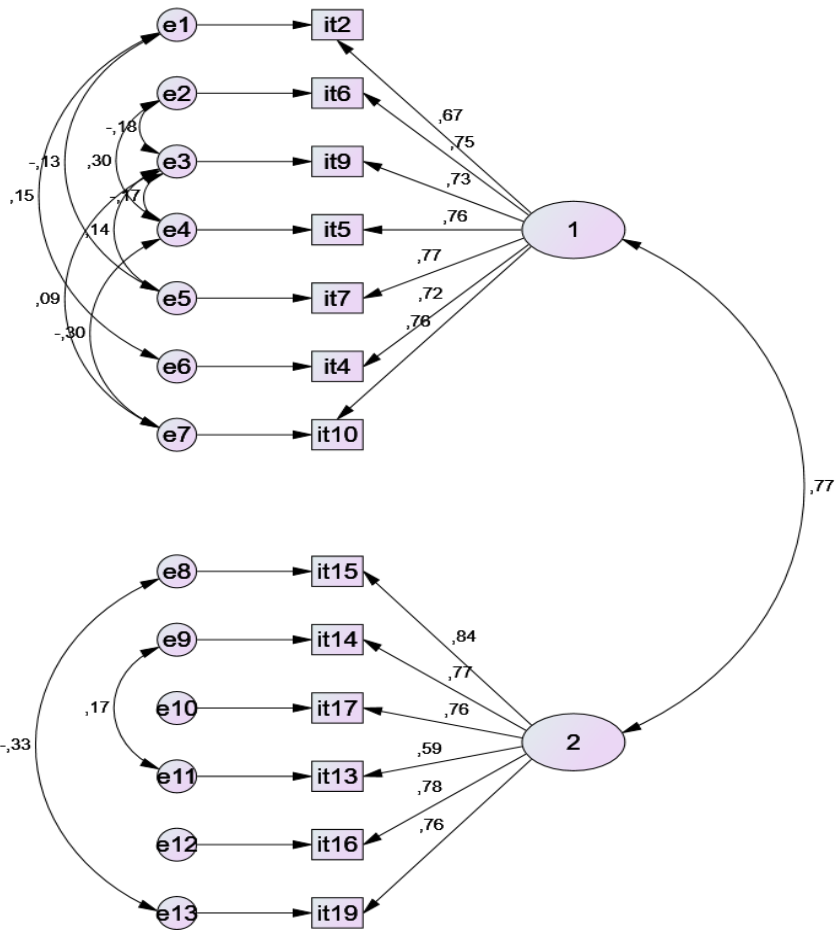

(CMIN/DF 2,638; SRMR 0,034; GFI 0,959; RMSEA 0,059; TLI 0,963; CFI 0,974).

\section{Figure 3. Job satisfaction measurement model}

The latent variables are named intrinsic job satisfaction (1) and extrinsic job satisfaction (2). The results of job satisfaction measurement model validity analyses are in Table 6 are satisfactory. 
Job Characteristics' Causal Effects on Individual Job Performance Perceptions...

Table 6. Validity analyses of job satisfaction

\begin{tabular}{ccccccc}
\hline & CR & AVE & MSV & MaxR(H) & $\mathbf{1}$ & $\mathbf{2}$ \\
\hline 1 IJS & 0.893 & 0.545 & 0.590 & 0.895 & 0.738 & \\
\hline 2 EJS & 0.887 & 0.569 & 0.590 & 0.897 & $0.768^{* * *}$ & 0.754 \\
\hline
\end{tabular}

Reliability $(C R>0,7)$, Convergent validity (AVE $>0,5)$, (CR $>A V E)$, Discriminant validity ( $M S V<A V E)$, Partly discriminant validity (ASV>inter-factor correlations).

The number of latent variables remained unchanged (Figure 4).

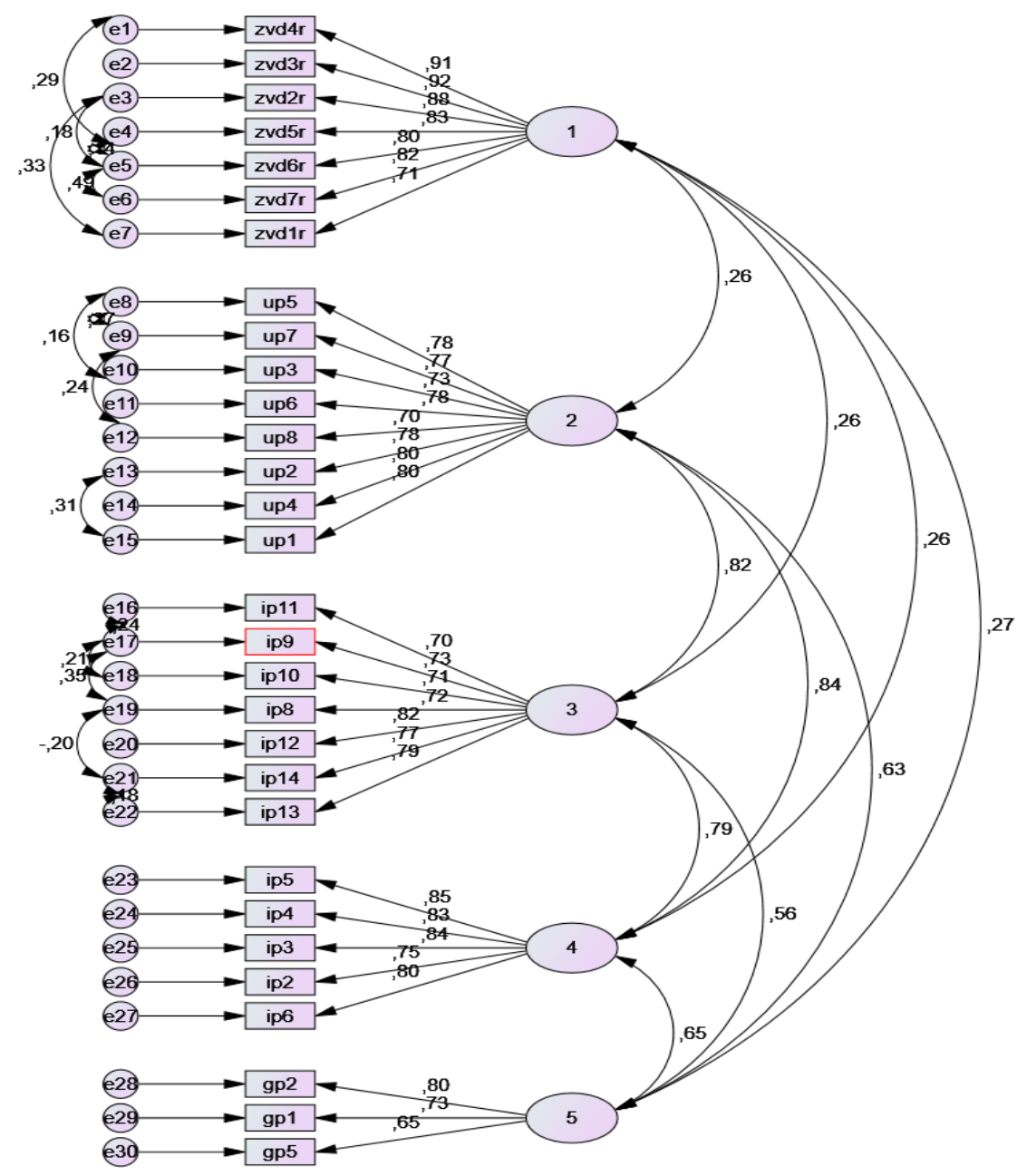

(CMIN/DF 1,921; SRMR 0,038; GFI 0,906; RMSEA 0,044; TLI 0,962; CFI 0,967).

Figure 4. Job performance perception measurement model 
The latent variables are named counterproductive work behavior (1), compliance performance (2), relational contextual performance (3), individual contextual performance (4), and task performance (5). The results of job performance measurement model validity analyses in Table 7 are satisfactory.

Table 7. Validity analyses of job performance perception

\begin{tabular}{cccccccccc}
\hline & CR & AVE & MSV & $\begin{array}{c}\text { Maks } \\
\text { R(H) }\end{array}$ & $\mathbf{1}$ & $\mathbf{2}$ & $\mathbf{3}$ & $\mathbf{4}$ & $\mathbf{5}$ \\
\hline 1 CWB & 0.944 & 0.708 & 0.075 & 0.954 & 0.842 & & & & \\
\hline 2 COP & 0.920 & 0.589 & 0.706 & 0.921 & $0.264^{* * *}$ & 0.768 & & & \\
\hline 3 RCP & 0.899 & 0.561 & 0.666 & 0.903 & $0.261^{* * *}$ & $0.816^{* * *}$ & 0.749 & & \\
\hline 4 ICP & 0.906 & 0.660 & 0.706 & 0.910 & $0.259^{* * *}$ & $0.840^{* * *}$ & $0.786^{* * *}$ & 0.812 & \\
\hline 5 TSP & 0.773 & 0.533 & 0.417 & 0.786 & $0.275^{* * *}$ & $0.629^{* * *}$ & $0.557^{* * *}$ & $0.645^{* * *}$ & 0.730 \\
\hline $\begin{array}{l}\text { Reliability (CR>0,7), Convergent validity (AVE>0,5), (CR>AVE), Discriminant validity (MSV<AVE), Partly } \\
\text { discriminant validity (ASV>inter-factor correlations) }\end{array}$
\end{tabular}

\subsection{Path model}

Based on the confirmatory factor analysis results, the factors and their subdimensions in the data set are averaged. The descriptive statistical values of the variables are presented in Table 8.

Table 8. Descriptive statistics and correlation matrix

\begin{tabular}{|c|c|c|c|c|c|c|c|c|c|c|c|}
\hline & $\overline{\mathbf{X}}$ & $s$ & FRI & SKV & AUT & IJS & EJS & COP & RCP & ICP & TSP \\
\hline FRI & 4.20 & 1.10 & - & & & & & & & & \\
\hline SKV & 4.33 & 1.13 & $0.562 * *$ & - & & & & & & & \\
\hline AT & 3.87 & 1.18 & $0.530 * *$ & $0.432 * *$ & - & & & & & & \\
\hline IJS & 4.27 & 1.09 & $0.475 * *$ & $0.440 * *$ & $0.339 * *$ & - & & & & & \\
\hline EJS & 3.87 & 1.22 & $0.405 * *$ & $0.307^{* *}$ & $0.422 * *$ & $0.679 * *$ & - & & & & \\
\hline $\mathrm{COP}$ & 4.61 & 1.11 & $0.515^{* *}$ & $0.529 * *$ & $0.302 * *$ & $0.456 * *$ & $0.250 * *$ & - & & & \\
\hline $\mathrm{RCP}$ & 4.17 & 1.10 & $0.475 * *$ & $0.397 * *$ & $0.405^{* *}$ & $0.835^{* *}$ & $0.844^{* *}$ & $0.355 * *$ & - & & \\
\hline ICP & 4.11 & 1.12 & $0.461^{* *}$ & $0.388 * *$ & $0.348^{* *}$ & $0.929 * *$ & $0.672 * *$ & $0.421 * *$ & $0.735^{* *}$ & - & \\
\hline TSP & 4.48 & 1.24 & $0.392 * *$ & $0.464 * *$ & $0.279 * *$ & $0.444 * *$ & $0.305^{* *}$ & $0.547 * *$ & $0.376 * *$ & $0.398 * *$ & - \\
\hline
\end{tabular}

The parameters indicated plausible dispersion. There were no multicollinearity problems $(\mathrm{VIF}<3$ ) among measurement variables in the equation (Hair et al., 2010). Moderate levels of correlations among research variables provided the basis for hypothesis testing on a path model (mean $r=0.45$ ).

The remaining endogenous latent variables in the final model had high $\mathrm{R} 2$ values as $\mathrm{IJS}=0.26$, EJS $=0.21, \mathrm{COP}=0.39, \mathrm{RCP}=0.84, \mathrm{ICP}=0.86$, and $\mathrm{TSP}=0.28$. This indicated that the model tested accounted for a quite large proportion of the variance in the measured items. All the significant path coefficients indicating causal effects are given in Figure 5. 
Job Characteristics' Causal Effects on Individual Job Performance Perceptions...

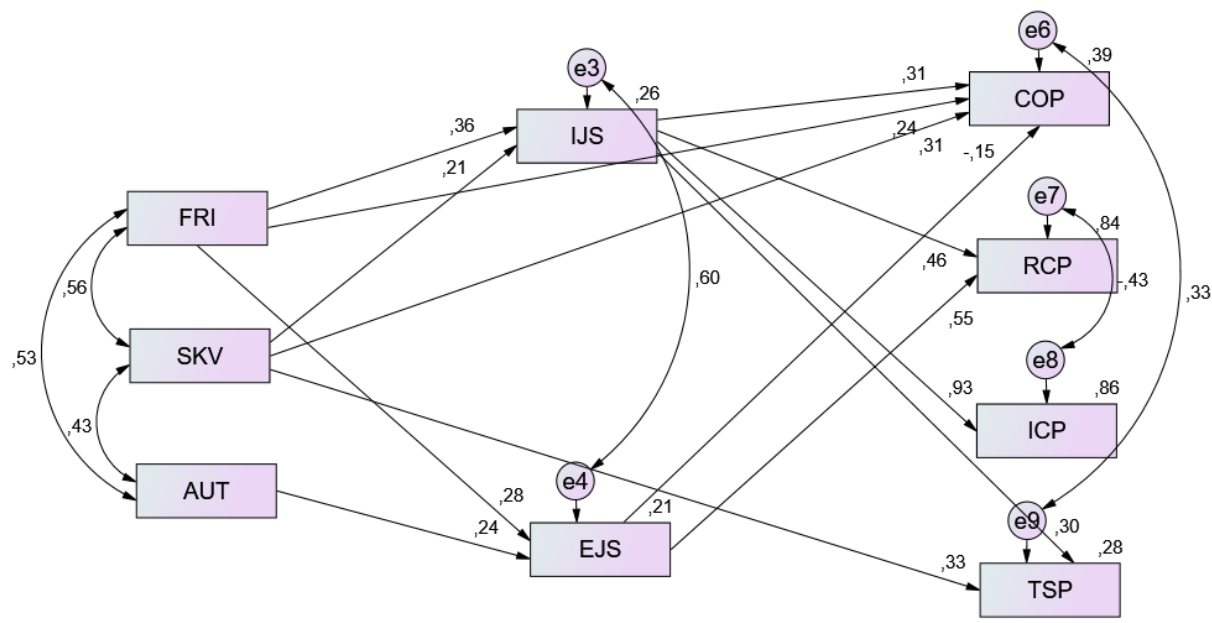

(CMIN/DF 2.272; SRMR 0.029; GFI 0.983; RMSEA 0.052; TLI 0.986; CFI 0.993)

\section{Figure 5. Path model with standardized regression coefficients}

The direct effects of job characteristics' dimensions on job satisfaction dimensions and job performance dimensions are tested and shown as statistically significant direct effects coefficients in Table 9.

\section{Table 9. Direct path coefficients of the hypothesized model}

\begin{tabular}{ccccccc}
\hline & Path & & S. estimate & S.E. & C.R. & P \\
\hline FRI & $\rightarrow$ & IJS & 0.358 & 0.046 & 7.937 & $* * *$ \\
\hline FRI & $\rightarrow$ & EJS & 0.281 & 0.052 & 6.121 & $* * *$ \\
\hline SKV & $\rightarrow$ & IJS & 0.213 & 0.037 & 5.534 & $* * *$ \\
\hline AUT & $\rightarrow$ & EJS & 0.240 & 0.040 & 6.190 & $* * *$ \\
\hline FRI & $\rightarrow$ & COP & 0.238 & 0.046 & 5.397 & $* * *$ \\
\hline SKV & $\rightarrow$ & COP & 0.306 & 0.043 & 6.922 & $* * *$ \\
\hline SKV & $\rightarrow$ & TSP & 0.334 & 0.047 & 7.780 & $* * *$ \\
\hline IJS & $\rightarrow$ & COP & 0.312 & 0.052 & 6.153 & $* * *$ \\
\hline IJS & $\rightarrow$ & RCP & 0.458 & 0.023 & 19.371 & $* * *$ \\
\hline IJS & $\rightarrow$ & ICP & 0.928 & 0.018 & 54.134 & $* * *$ \\
\hline IJS & $\rightarrow$ & TSP & 0.297 & 0.049 & 6.924 & $* * *$ \\
\hline EJS & $\rightarrow$ & COP & -0.151 & 0.042 & -3.271 & 0.001 \\
\hline EJS & $\rightarrow$ & RCP & 0.545 & 0.020 & 24.440 & $* * *$ \\
\hline$* 0.05{ }^{* *<0.01}{ }^{* * *}<0.001$ & & & &
\end{tabular}

Job characteristics' influence on job performance: Skill variety significantly and positively affects compliance performance $(\beta=0.306, p<0.001)$ and task performance $(\beta=0.334, p<0.001)$-the hypothesis $\mathrm{H} 1$. Skill variety has a significant positive influence on job performance supported - the hypothesis H2. Autonomy has a significant positive influence on job performance not supported as there found no 
quantitative evidence. Friendship significantly and positively affects compliance performance $(\beta=0.238, p<0.001)$-the hypothesis H3. Friendship has a significant positive influence on job performance supported.

Job characteristics' influence on job satisfaction: Autonomy significantly and positively affects extrinsic job satisfaction $(\beta=0.240, p<0.001)$-the hypothesis $\mathrm{H} 4$. Autonomy has a significant positive influence on job satisfaction supported. Skill variety significantly and positively affects intrinsic job satisfaction $(\beta=0.213$, $\mathrm{p}<0.001$ ) - the hypothesis $\mathrm{H} 5$. Skill variety has a significant positive influence on job satisfaction supported. Friendship significantly and positively affects intrinsic job satisfaction $(\beta=0.358, p<0.001)$ and extrinsic job satisfaction $(\beta=0.281, p<0.001)$ the hypothesis $\mathrm{H6}$. Friendship has a significant positive influence on job satisfaction supported.

Job satisfaction's influence on job performance: Intrinsic job satisfaction has a significant and positive influence on compliance performance $(\beta=0.312, p<0.001)$, relational contextual performance $(\beta=0.458, p<0.001)$, individual contextual performance $(\beta=0.928, p<0.001)$, and task performance $(\beta=0.297, p<0.001)$. Extrinsic job satisfaction significantly and positively influences relational con-textual performance $(\beta=0.545, p<0.001)$. But extrinsic job satisfaction significantly and negatively affects compliance performance $(\beta=-0.151, p<0.01)$, regarding the reverse effect of extrinsic job satisfaction on compliance performance, hypothesis H7. Job satisfaction has a significant positive influence on job performance is partly supported.

\subsection{Mediation of job satisfaction}

The mediation effects are tested on the path model with the bootstrap technique as a more advantageous method over others that is based on the biased corrected confidence interval (Hair et al., 2010; MacKinnon et al., 2007; Shrout \& Bolger, 2002). The specific indirect effects plugin is used for calculating all possible mediating effects between variables in the path model (Gaskin \& Lim, 2018). The bootstrap analysis calculated a $95 \%$ confidence interval on the path model with 472 samples. The results are given in Table 10 .

The intrinsic job satisfaction's full mediations revealed that friendship has significant and positive influence on relational contextual performance $(\beta=0.164, p<0.01, B C$, $\mathrm{Cl}=0.125$ ? 0.208), individual contextual performance $(\beta=0.333, \mathrm{p}<0.001, \mathrm{BC}, \mathrm{Cl}=$ 0.271 ? 0,428) and task performance $(\beta=0.107, \mathrm{p}<0.001, \mathrm{BC}, \mathrm{Cl}=0.081$ ? 0.173) which originally did not exist. The extrinsic job satisfaction' full mediating role revealed that friendship has significant and positive effect on relational contextual performance $(\beta=0.153, p<0.001, B C, C l=0.110$ ? 0.208 ) which originally did not exist. The intrinsic job satisfaction's full mediations revealed that skill variety has significant and positive effect on relational contextual performance $(\beta=0.098, p<$ $0.001, \mathrm{BC}, \mathrm{Cl}=0.065$ ? 0.123), and individual contextual performance $(\beta=0.198, p<$ $0.001, \mathrm{BC}, \mathrm{Cl}=0.137$ ? 0.254) which originally did not exist. 
Job Characteristics' Causal Effects on Individual Job Performance Perceptions...

Table 10. Indirect path coefficients of hypothesized model

\begin{tabular}{llllll}
\hline Indirect Path & Lower & Upper & P-Value & $\begin{array}{l}\text { Standardized } \\
\text { Estimate }\end{array}$ & Mediation \\
\hline $\mathrm{FRI} \rightarrow \mathrm{IJS} \rightarrow \mathrm{COP}$ & 0.076 & 0.168 & 0.001 & $0.112^{* * *}$ & Partial \\
\hline $\mathrm{FRI} \rightarrow \mathrm{IJS} \rightarrow \mathrm{RCP}$ & 0.125 & 0.208 & 0.001 & $0.164^{* *}$ & Full \\
\hline $\mathrm{FRI} \rightarrow \mathrm{IJS} \rightarrow \mathrm{ICP}$ & 0.271 & 0.428 & 0.001 & $0.333^{* * *}$ & Full \\
\hline $\mathrm{FRI} \rightarrow \mathrm{IJS} \rightarrow \mathrm{TSP}$ & 0.081 & 0.173 & 0.001 & $0.107^{* * *}$ & Full \\
\hline $\mathrm{FRI} \rightarrow \mathrm{EJS} \rightarrow \mathrm{COP}$ & -0.079 & -0.021 & 0.001 & $-0.042^{* * *}$ & Partial Negative \\
\hline $\mathrm{FRI} \rightarrow \mathrm{EJS} \rightarrow \mathrm{RCP}$ & 0.110 & 0.208 & 0.001 & $0.153^{* * *}$ & Full \\
\hline $\mathrm{SKV} \rightarrow \mathrm{IJS} \rightarrow \mathrm{COP}$ & 0.042 & 0.097 & 0.001 & $0.066^{* * *}$ & Partial \\
\hline $\mathrm{SKV} \rightarrow \mathrm{IJS} \rightarrow \mathrm{RCP}$ & 0.065 & 0.123 & 0.001 & $0.098^{* * *}$ & Full \\
\hline $\mathrm{SKV} \rightarrow \mathrm{IJS} \rightarrow \mathrm{ICP}$ & 0.137 & 0.254 & 0.001 & $0.198^{* * *}$ & Full \\
\hline $\mathrm{SKV} \rightarrow \mathrm{IJS} \rightarrow \mathrm{TSP}$ & 0.046 & 0.100 & 0.000 & $0.063^{* * *}$ & Partial \\
\hline $\mathrm{AUT} \rightarrow \mathrm{EJS} \rightarrow \mathrm{COP}$ & -0.057 & -0.017 & 0.001 & $-0.036^{* * *}$ & Full Negative \\
\hline $\mathrm{AUT} \rightarrow \mathrm{EJS} \rightarrow \mathrm{RCP}$ & 0.082 & 0.157 & 0.001 & $0.131^{* * *}$ & Full \\
\hline$* 0.05{ }^{* *}<0.01 \quad * * *<0.001$ & & & &
\end{tabular}

The extrinsic job satisfaction's full mediation revealed that autonomy has significant and positive effect on relational contextual performance $(\beta=0.131, p<0.001, \mathrm{BC}, \mathrm{Cl}$ $=0.082$ a 0.157 ) which originally did not exist. The extrinsic job satisfaction's full mediation revealed that autonomy has significant and negative effect on compliance performance $(\beta=-0.036, p<0.001, \mathrm{BC}, \mathrm{Cl}=-0.057$ 目 -0.017 ) which originally did not exist.

The intrinsic job satisfaction positively and partially mediated friendship's positive effect on compliance performance $(\beta=0.112, p<0.001, \mathrm{BC}, \mathrm{Cl}=0.076$ 0.168). The intrinsic job satisfaction positively and partially mediated skill variety's positive effects on compliance performance $(\beta=0.066, p<0.001, \mathrm{BC}, \mathrm{Cl}=0.042$. 0.097) and task performance $(\beta=0.063, p<0.001, \mathrm{BC}, \mathrm{Cl}=0.046$ a 0.100$)$. The extrinsic job satisfaction negatively and partially mediated friendship's positive effect on compliance performance $(\beta=-0.042, p<0.001, \mathrm{BC}, \mathrm{Cl}=-0.079$ ] -0.021$)$.

In the final evaluation of mediation findings - hypothesis H8- job characteristics' influence on job performance is positively mediated by job satisfaction is partly supported regarding the extrinsic job satisfaction's negative indirect effect on job performance.

\section{Discussion}

According to the results, job characteristics have a positive influence on both job satisfaction and job performance perception. On the other hand, job satisfaction's influence on job performance perception is both in positive and negative directions. The hypotheses tested for the subdimensions of the structures in the study revealed various results that offer implications for theory and practice. 


\subsection{Theoretical implications}

Results from the Turkish sample confirmed job characteristics' direct influence on job performance evaluation and supported similar findings of previous empirical studies. The contributions made to human resource management literature are explained in detail below.

The descriptive findings of the study provided insights into the correlations among job characteristics, job satisfaction, and job performance perception. The highest mean values for skill variety $(\bar{X}=4.33)$ were found to be similar to the findings of a study in Latin American culture (Peiró et al., 2020).

The results indicated that skill variety has a direct positive impact on compliance performance and task performance. The findings are aligned with the assumptions of work design theory (Grant et al., 2009) and empirical research findings. General support came from the findings of various research (Johari \& Yahya, 2016; Millette \& Gagné, 2008; Peiró et al., 2020; Singh, 1998; Tyagi, 1985). In other words, when the employees perceive their job as more enriched, their compliance and task performances will be higher. Friendship had a significant and positive effect on compliance performance. Friendship could increase compliance performance by promoting positive interactions among people and enhancing the social exchange relationship's quality between co-workers and supervisors. This is supported by Sarıköse \& Göktepe's (2021) empirical findings showing that staffing and colleague solidarity are important factors affecting job performance. But there found no evidence about autonomy's effect on job performance.

Autonomy had a direct positive effect on extrinsic job satisfaction. This finding is supported by some empirical evidence about job characteristics' effect on extrinsic (García et al., 2019) and overall job satisfaction (Ali et al., 2014; Dore, 2004; Ford \& Wooldridge, 2012; Giles et al., 2017; Millette \& Gagné, 2008; Riasudeen \& Venkatesa-kumar, 2014; Singh, 1998; Van den berg \& Feij, 2003). It can be concluded that the employees with autonomous jobs have more extrinsic job satisfaction.

Skill variety had a direct positive effect on intrinsic job satisfaction, which is aligned with some empirical research results in the related literature (Ali et al., 2014; Dore, 2004; Ford \& Wooldridge, 2012; Jansen et al., 1996; Millette \& Gagné, 2008; Namm, 2003; Riasudeen \& Venkatesakumar, 2014; Van den berg \& Feij, 2003). It can be concluded that when the employees perceive their job as more enriched, their intrinsic job satisfaction will be higher.

Friendship had a positive influence on both extrinsic and intrinsic job satisfaction. This finding had a base in social exchange theory in which the employees with intrinsic job satisfaction enhance the quality of the social exchange for individuals in the workplace relationships.

Intrinsic job satisfaction had a quite high level of effect size, explaining $84 \%$ of the total variance for relational contextual performance (R2=0.84) and $86 \%$ of the total 
Job Characteristics' Causal Effects on Individual Job Performance Perceptions...

variance for individual contextual performance $(R 2=0.86)$. This is interpreted as the employees with a chance to use their abilities and feeling of accomplishment are likely to be industrious and resourceful people with extra-role behaviors at work.

Intrinsic job satisfaction had a positive influence on compliance performance, relational contextual performance, individual contextual performance, and task performance. This finding is generally supported by some empirical findings ( $\mathrm{Al}$, 2016; Astuti et al., 2020; Edward \& Kaban, 2020; Gül et al., 2008; Idris et al., 2020; Keaweney \& Nelson, 1993; Marbawi et al., 2018; Mardanov, 2020; Perera et al., 2014; Riyadi, 2019; Shafique et al., 2018; Topcu et al., 2017; Yustina \& Valerina, 2018). This means that when the employees have intrinsic job satisfaction, their overall (compliance, relational contextual, individual contextual, and task) performance will be higher. Extrinsic job satisfaction had a positive effect on relational contextual performance. This is supported by the findings of the study in Nigeria (Funmilola et al., 2013). This means that when employees have extrinsic job satisfaction, their relational contextual performance will be higher. Extrinsic job satisfaction is found to negatively influence compliance performance. This may be interpreted that the employees who are satisfied by advancement, payment, and recognition are prone to have difficulties in adapting to changes and coping with uncertainties at work.

Findings were consistent with the previous empirical evidence that agreed on job satisfaction's positive effect on job performance (Al-Ahmadi, 2009; Jung Choi \& Tae Kim, 2012). Our findings were aligned with the literature as intrinsic job satisfaction is more critical than extrinsic job satisfaction on job performance (Hackman \& Oldham, 1975; Tyagi, 1985). Findings contribute to the social exchange theory in that individuals have better performance when they are pleased and satisfied with the advantages of the exchange in the workplace (Blau, 1964).

This study deepens the understanding of the mediation role of job satisfaction on job characteristics' influence on job performance perception by revealing details. Friendship acquires positive effects on the relational contextual, individual contextual, and task performances through intrinsic job satisfaction's full mediation. Friendship acquires a positive effect on the relational contextual performance through extrinsic job satisfaction's full mediation. The finding is supported by empirical evidence (Idris et al., 2020; Yustina \& Valerina, 2018) and contributed to the modern job design approach (Grant et al., 2009). The individuals who perceive friendship as a character of their job have a better relational contextual performance perception as they have more extrinsic job satisfaction. Skill variety acquires positive effects on the relational and individual contextual performances through intrinsic job satisfaction's full mediation. Autonomy acquires a positive effect on relational contextual performance through extrinsic job satisfaction's full mediation. To conclude, job satisfaction as a full mediator revealed that friendship, skill variety, and autonomy had positive determination on job performance. 
Autonomy acquires a negative effect on compliance performance through extrinsic job satisfaction's full mediation. To conclude, extrinsic job satisfaction as a full mediator revealed that autonomy negatively influences compliance performance.

Friendship's positive effect on compliance performance will be higher through intrinsic job satisfaction's partial positive mediation. Skill variety's positive effect on compliance and task performances will be higher through intrinsic job satisfaction's partial positive mediation. Friendship's positive effect on compliance performance will be lower through extrinsic job satisfaction's partial negative mediation. The mediation effects of job satisfaction found between the job characteristics' dimensions and job performance perception are the most important contribution of the study to the theory (Idris et al., 2020; Yustina \& Valerina, 2018). The dimensions of job characteristics acquiring direct effects on the dimensions of job performance showed that job satisfaction has an important mediating role in this relationship. Testing the mediating effects in a sample from the service industry is another aspect of the study's contribution to the literature.

The use of structural equation modeling as a robust method in the study allows future research to make more precise comparisons about the relationships among the dimensions of job performance and job characteristics.

The results of the study suggest that the employees should have sufficient control over their job to accomplish their job tasks. The jobs should be designed fairly autonomous. Many other benefits along with individual job performance may be attained when the work redesign is retained as an active change and intervention instrument by the management. The findings comply with management concepts suggesting less control and supervision in teamwork, empowerment, and flexibility.

\subsection{Practical implications}

Our findings have important implications for human resource managers in the job designing process. According to the findings of the study, adapting to the new work system, colleagues and roles are hard for the employees whose jobs are designed with autonomy and friendship as dominant characters. A high level of extrinsic job satisfaction may result in negative compliance performance for these kinds of jobs. Managers are advised to determine the adequate level of extrinsic satisfaction such as job security, recognition from the company for these kinds of jobs in case of reorganizing and reengineering.

The human resource managers are also advised to use each job characteristic as a criterion in personnel selection and compensation to have substantial job performance improvements in complicated jobs and tasks.

\section{Conclusion and Limitations}

The main ideas of the study were verified that job characteristics have meaningful effects on job performance and that job satisfaction has a mediating role in this 
Job Characteristics' Causal Effects on Individual Job Performance Perceptions...

relationship. There found some exceptional findings as well: Extrinsic job satisfaction negatively influences compliance performance; Autonomy acquires a negative effect on compliance performance through extrinsic job satisfaction's full mediation; Friendship's positive effect on compliance performance will be lower through extrinsic job satisfaction's partial negative mediation.

The findings should be interpreted with some limitations. Survey data on job performance were gathered from employees due to organizational characteristics. The performance evaluation of supervisors who have no turnover concerns could reflect the more realistic performance of employees and reduce common-method variance. But the findings of a study in which common method variance was controlled showed that core job characteristics have significant effects on job performance despite gathering all survey data from the same source (Glick et al., 1986). Another limitation is that the survey sample was not heterogeneous due to volunteer participation in the survey. Future studies should have more heterogeneous samples to generalize findings.

\section{References}

Abramis, D. J. (1994). Work role ambiguity, job satisfaction, and job performance: Metaanalyses and review. Psychological Reports, 75(3), 1411-1433. https://doi.org/10.2466/pr0.1994.75.3f.1411

Al, A. (2016). Kısmi zamanlı çalışanlarla tam zamanlı çalışanların bireysel performans düzeylerinde iş tatmininin rolü [Master Thesis]. Marmara University.

Al-Ahmadi, H. (2009). Factors affecting performance of hospital nurses in Riyadh region, Saudi Arabia. International Journal of Health Care Quality Assurance, 22(1), 40-54. https://doi.org/10.1108/09526860910927943

Algera, J. A., Flier, H. Van de \& Kamp, L. J. T. Van de. (1986). Causal modelling of quality of work. In C. Debus \& H. W. Schroiff (Eds.), The Psychology of Work and Organization, Elsevier Science Publishers, North-Holland.

Ali, S. A. M., Said, N. A., Yunus, N. M., Kader, S. F. A., Latif, D. S. A., \& Munap, R. (2014). Hackman and Oldham's Job Characteristics Model to Job Satisfaction. Procedia - Social and Behavioral Sciences, 129, 46-52. https://doi.org/10.1016/i.sbspro.2014.03.646

Aslan, M. (2017). Yönetici liderlik tarzları ile çalışan performansı arasındaki ilişki: Bir kargo şirketinde uygulama [Master Thesis]. Beykent University.

Astuti, S. D., Shodikin, A., \& Ud-Din, M. (2020). Islamic leadership, Islamic work culture, and employee performance: The mediating role of work motivation and job satisfaction. The Journal of Asian Finance, Economics and Business, 7(11), 1059-1068. https://doi.org/10.13106/JAFEB.2020.VOL7.NO11.1059

Bakan, Y. D. D. I., \& Büyükbeşe, A. G. T. (2004). Çalışanların iş güvencesi ve genel iş davranışları ilişkisi: Bir alan çalışması. Erciyes Üniversitesi Iktisadi ve Idari Bilimler Fakültesi Dergisi, (23), https://dergipark.org.tr/tr/pub/erciyesiibd/issue/5880/77807

Bell, J., Yang, Y. F., \& Islam, M. (2012). The influence of transformational leadership on job satisfaction: The balanced scorecard perspective. Journal of Accounting \& Organizational Change, 8(3), 386-402. https://doi.org/10.1108/18325911211258353 
Blau, P. (1964). Exchange and power in social life. Wiley.

Bollen, K., \& Lennox, R. (1991). Conventional wisdom on measurement: A structural equation perspective. Psychological Bulletin, 110, 305-314. https://doi.org/10.1037/00332909.110.2.305.

Boomsma, A. (1982). Robustness of LISREL against small sample sizes in factor analysis models. In K. Jöreskog \& H. Wold (Eds.), Systems Under Indirection Observation: Causality, Structure, Prediction (Part I) (pp. 149-173).

Boumans, N. P. G. (1990). Het werk van verpleegkundige in algemene ziekenhuizen: een onderzoek naar werkaspecten en hun invloed op verpleegkundigen, [Doctoral dissertation, University of Limburg], Maastricht. https://doi.org/10.26481/dis.19900406nb

Bowling, A. (2002). Research Methods in Health: Investigating Health and Health Services (2nd ed). Open University Press.

Browne, M. W., \& Cudeck, R. (1992). Alternative ways of assessing model fit. Sociological Methods \& Research, 21(2), 230-258. https://doi.org/10.1177/0049124192021002005

Choo, F. (1986). Job stress, job-performance, and auditor personality-characteristics. AuditingA Journal of Practice \& Theory, 5(2), 17-34.

Cooper, C. L., \& Rout, U., \& Faragher, B. (1989). Mental health, job satisfaction, and job stress among general practitioners. BMJ Clinical Research, 298, 366-370. https://doi.org/10.1136/bmj.298.6670.366.

Cox, T., \& Nkomo, S. M. (1986). Differential performance appraisal criteria: A field study of black and white managers. Group \& Organization Studies, 11(1-2), 101-119.

Dinc, M. S., \& Plakalovic, V. (2016). Impact of Caring Climate, Job Satisfaction, and Affective Commitment on Employees Performance in the Banking Sector of Bosnia and Herzegovina. Eurasian Journal of Business and Economics, 9(18), 1-16. https://doi.org/10.17015/ejbe.2016.018.01

Dore, T. (2004). The relationships between job characteristics, job satisfaction, and turnover intention among software developers [Ph. D.]. Argosy University.

Edward, Y. R., \& Kaban, L. M. (2020). The effect of transformational leadership and competence on employee performance with job satisfaction as intervening variable. Academic Journal of Economic Studies, 6(2), 62-72.

Fields, D. L. (2002). Taking the Measure of Work: A Guide to Validated Scales for Organizational Research and Diagnosis. Sage. https://doi.org/10.4135/9781452231143

Ford, M. T., \& Wooldridge, J. D. (2012). Industry growth, work role characteristics, and job satisfaction: A cross-level mediation model. Journal of Occupational Health Psychology, 17(4), 492-504. https://doi.org/10.1037/a0029535

Fried, Y., \& Ferris, G. R. (1987). The validity of the job characteristics model: A review and meta-analysis. Personnel Psychology, 40(2), 287-322. https://doi.org/10.1111/j.17446570.1987.tb00605.x

Funmilola, O. F., Sola, K. T., \& Olusola, A. G. (2013). Impact of job satisfaction dimensions on job performance in a small and medium enterprise in Ibadan, South-Western, Nigeria. Interdisciplinary Journal of Contemporary Research in Business, 4(11), 509-521.

García, D. M., Molina, I. R., \& Marco, J. M. (2019). The effect of job characteristics on intrinsic and extrinsic job satisfaction: The moderating role of psychological capital. Psychologica, 62(1), 39-56. https://doi.org/10.14195/1647-8606 62-1 2 
Job Characteristics' Causal Effects on Individual Job Performance Perceptions...

Gaskin, J., \& Lim, J. (2018). Indirect Effects. AMOS Plugin.

Gibson Jr., T. O., Morrow, J. A., \& Rocconi, L. M. (2020). A Modernized Heuristic Approach to Robust Exploratory Factor Analysis. The Quantitative Methods for Psychology, 16(4), 295-307. https://doi.org/10.20982/tamp.16.4.p295

Giles, M., Parker, V., Mitchell, R., \& Conway, J. (2017). How do nurse consultant job characteristics impact on job satisfaction? An Australian quantitative study. BMC Nursing, 16(1), 51. https://doi.org/10.1186/s12912-017-0246-y

Glick, W. H., Jenkins Jr, G. D., \& Gupta, N. (1986). Method versus substance: How strong are underlying relationships between job characteristics and attitudinal outcomes?. Academy of Management Journal, 29(3), 441-464.

Grant, A., Fried, Y., \& Juillerat, T. (2009). Work Matters: Job Design in Classic and Contemporary Perspectives. APA Handbook of Industrial and Organizational Psychology, 1. https://doi.org/10.1037/12169-013

Gül, H., Oktay, E., \& Gökçe, H. (2008). İş tatmini, stres, örgütsel bağlılık, işten ayrılma niyeti ve performans arasındaki ilişkiler: Sağlık sektöründe bir uygulama. Akademik Bakış, Uluslararası Hakemli Sosyal Bilimler E-Dergisi, 20, 1-11.

Hackman, J. R., \& Lawler, E. E. (1971). Employee reactions to job characteristics. Journal of Applied Psychology, 55(3), 259-286. https://doi.org/10.1037/h0031152

Hackman, J. R., \& Oldham, G. R. (1975). Development of the Job Diagnostic Survey. Journal of Applied Psychology, 60(2), 159-170. https://doi.org/10.1037/h0076546

Hackman, J. R., \& Oldham, G. R. (1976). Motivation through the design of work: Test of a theory. Organizational Behavior and Human Performance, 16(2), 250-279. https://doi.org/10.1016/0030-5073(76)90016-7

Hackman, J., \& Oldham, G. (1974). The job diagnostic survey: An instrument for the diagnosis of jobs and the evaluation of job redesign projects. Department of Administrative Sciences: Yale University. https://doi.org/10.1037/t02285-000

Hair, J., Black, W., Babin, B., \& Anderson, R. (2010). Multivariate Data Analysis: A Global Perspective. Prentice-Hall.

Hartline, M. D., \& Ferrell, O. C. (1996). The management of customer-contact service employees: An empirical investigation. Journal of Marketing, 60(4), 52-70. https://doi.org/10.2307/1251901

Hoyle, R. (1995). Structural equation modeling: Concepts, issues, and applications. Sage Publications Inc.

Hu, L., \& Bentler, P. M. (1999). Cutoff criteria for fit indexes in covariance structure analysis: Conventional criteria versus new alternatives. Structural Equation Modeling: $A$ Multidisciplinary Journal, 6(1), 1-55. https://doi.org/10.1080/10705519909540118

Humphrey, S. E., Nahrgang, J. D., \& Morgeson, F. P. (2007). Integrating motivational, social, and contextual work design features: A meta-analytic summary and theoretical extension of the work design literature. Journal of Applied Psychology, 92(5), 1332-1356. https://doi.org/10.1037/0021-9010.92.5.1332

Idaszak, J. R., \& Drasgow, F. (1987). A revision of the Job Diagnostic Survey: Elimination of a measurement artifact. Journal of Applied Psychology, 72(1), 69-74. https://doi.org/10.1037/0021-9010.72.1.69 
Idris, I., Adi, K. R., Soetjipto, B. E., \& Supriyanto, A. S. (2020). The mediating role of job satisfaction on compensation, work environment, and employee performance: Evidence from Indonesia. Entrepreneurship and Sustainability Issues, 8(2), 735-750. https://doi.org/10.9770/jesi.2020.8.2(44)

Jamil, B., \& Raja, N. S. (2011). Impact of Compensation, Performance Evaluation and Promotion Practices on Government Employees Performance vs. Private Employees Performance. Interdisciplinary Journal of Contemporary Research in Business, 3(8), 907-913.

Jansen, P. G. M., Kerkstra, A., Abu-Saad, H. H., \& Van Der Zee, J. (1996). The effects of job characteristics and individual characteristics on job satisfaction and burnout in community nursing. International Journal of Nursing Studies, 33(4), 407-421. https://doi.org/10.1016/0020-7489(95)00060-7

Johari, J., \& Yahya, K. K. (2016). Job characteristics, work involvement, and job performance of public servants. European Journal of Training and Development, 40(7), 554-575. https://doi.org/10.1108/EJTD-07-2015-0051

Jones, A., Norman, C. S., \& Wier, B. (2010). Healthy lifestyle as a coping mechanism for role stress in public accounting. Behavioral Research in Accounting, 22(1), 21-41. https://doi.org/10.2308/BRIA.2010.22.1.21

Jöreskog, K., \& Sörbom, D. (1989). LISREL 7: A guide to the program and applications. SPSS, Inc.

Judge, T. A., Thoresen, C. J., Bono, J. E., \& Patton, G. (2001). The Job Satisfaction-Job Performance Relationship: A Qualitative and Quantitative Review. Psychological Bulletin, 127, 379-407. https://doi.org/10.1037/0033-2909.127.3.376

Jung Choi, H., \& Tae Kim, Y. (2012). Work-family conflict, work-family facilitation, and job outcomes in the Korean hotel industry. International Journal of Contemporary Hospitality Management, 24(7), 1011-1028. https://doi.org/10.1108/09596111211258892

Keaweney, S. M., \& Nelson, J. E. (1993). Coping with organizational role stress: Intrinsic motivational orientation, perceived role benefits, and psychological withdrawal. Journal of the Academy of Marketing Science, 21(2), 113-124. https://doi.org/10.1007/BF02894422

Kinicki, A., \& Fugate, M. (2016). Organizational behavior: A practical, problem-solving approach (First edition). McGraw-Hill Education.

Kline, R. (2015). Principles and practice of structural equation modeling. The Guilford Press.

Koopmans, L., Bernaards, C. M., Hildebrandt, V. H., Schaufeli, W. B., de Vet Henrica, C., \& van der Beek, A. J. (2011). Conceptual frameworks of individual work performance: A systematic review. Journal of Occupational and Environmental Medicine, 53(8), 856-866. PubMed. https://doi.org/10.1097/jom.0b013e318226a763

Loewenthal, K. (2004). An introduction to psychological tests and scales (2nd ed.). Taylor and Francis Group.

Loher, B. T., Noe, R. A., Moeller, N. L., \& Fitzgerald, M. P. (1985). A Meta-Analysis of the Relation of Job Characteristics to Job Satisfaction. Journal of Applied Psychology, 70(2), 280289. https://doi.org/10.1037/0021-9010.70.2.280

Lynch, P. D., Eisenberger, R., \& Armeli, S. (1999). Perceived organizational support: Inferior versus superior performance by wary employees. Journal of Applied Psychology, 84(4), 467483. http://dx.doi.org/10.1037/0021-9010.84.4.467 
Job Characteristics' Causal Effects on Individual Job Performance Perceptions...

Mabaso, C. M., \& Dlamini, B. I. (2017). Impact of Compensation and Benefits on Job Satisfaction. Research Journal of Business Management, 11(2), 80-90. https://doi.org/10.3923/rjbm.2017.80.90

MacCallum, R. C., Browne, M. W., \& Sugawara, H. M. (1996). Power Analysis and Determination of Sample Size for Covariance Structure Modeling. Psychological Methods, 1, 130-149. https://doi.org/10.1037/1082-989X.1.2.130

Macdonald, S., \& Maclntyre, P. (1997). The generic job satisfaction scale: Scale development and its correlates. Employee Assistance Quarterly, 13(2), 1-16. https://doi.org/10.1300/J022v13n02 01

MacKinnon, D. P., Fairchild, A. J., \& Fritz, M. S. (2007). Mediation Analysis. Annual Review of Psychology, 58(1), 593-614. https://doi.org/10.1146/annurev.psych.58.110405.085542

Marbawi, L., Nurbaity, L., \& Siahaan, E. (2018). The influence of organizational culture, individual characteristics, and transformational leadership style on the job satisfaction and performance of employees in Indonesia. Quality - Access to Success, 19(163), 43-46.

Mardanov, I. (2020). Intrinsic and extrinsic motivation, organizational context, employee contentment, job satisfaction, performance and intention to stay. Evidence-Based HRM: A Global Forum for Empirical Scholarship, 9(3), 223-240. https://doi.org/10.1108/EBHRM-022020-0018

Marques-Quinteiro, P., \& Curral, L. A. (2012). Goal orientation and work role performance: Predicting adaptive and proactive work role performance through self-leadership strategies. Journal of Psychology, 146(6), 559-577. https://doi.org/10.1080/00223980.2012.656157

Millette, V., \& Gagné, M. (2008). Designing volunteers' tasks to maximize motivation, satisfaction and performance: The impact of job characteristics on volunteer engagement. Motivation and Emotion, 32(1), 11-22. https://doi.org/10.1007/s11031-007-9079-4

Morgeson, F., \& Humphrey, S. (2008). Job and team design: Toward a more integrative conceptualization of work design. Research in Personnel and Human Resources Management, 27, 39-91. https://doi.org/10.1016/S0742-7301(08)27002-7

Murphy, K. R. (1989). Dimensions of Job Performance. In R. F. Dillion \& J. W. Pelligrino (Eds.), Testing: Theoretical and Applied Perspectives. Praeger. https://doi.org/10.21236/ADA194951

Namm, S. (2003). The job characteristics-organizational citizenship behaviour relationship: A test of competing models [Ph. D.]. Temple University. https://doi.org/10.1037/e518632013$\underline{128}$

Netemeyer, R., Bearden, W., \& Sharma, S. (2003). Scaling procedures. Issues and applications. Sage Publications. https://doi.org/10.4135/9781412985772

Oldham, G. R. \& Hackman, J. R. (2010). Not what it was and not what it will be: The future of job design research. Journal of Organizational Behavior, 31(2-3), 463-479. https://doi.org/10.1002/job.678

Park, R., \& Searcy, D. (2012). Job Autonomy as a Predictor of Mental Well-Being: The Moderating Role of Quality-Competitive Environment. Journal of Business and Psychology, 27. https://doi.org/10.1007/s10869-011-9244-3

Parker, S., \& Wall, T. D. (1998). Job and work design: Organizing work to promote well-being and effectiveness (Vol. 4). Sage Publications. https://doi.org/10.4135/9781452231518

Pedhazur, E. (1997). Multiple regression in behavioral research: Explanation and prediction. Wadsworth. 
Peiró, J. M., Bayona, J. A., Caballer, A., \& Di Fabio, A. (2020). Importance of work characteristics affects job performance: The mediating role of individual dispositions on the work designperformance relationships. Personality and Individual Differences, 157, 109808. https://doi.org/10.1016/i.paid.2019.109808

Perera, G. D. N., Khatibi, A., Navaratna, N., \& Chinna, K. (2014). Job satisfaction and job performance among factory employees in apparel sector. Asian Journal of Management Sciences and Education, 3(1), 10.

Podsakoff, P., MacKenzie, S., Moorman, R., \& Fetter, R. (1990). Transformational leader behaviors and their effects on followers' trust in leader, satisfaction, and organizational citizenship behaviors. The Leadership Quarterly, 1(2), 107-142. https://doi.org/10.1016/10489843(90)90009-7.

Riasudeen, S., \& Venkatesakumar, R. (2014). Mediating role of job satisfaction in the relationship between task characteristics and life satisfaction. Indore Management Journal, 6, 25-34.

Riyadi, S. (2019). The influence of job satisfaction, work environment, individual characteristics and compensation toward job stress and employee performance. International Review of Management and Marketing, 9(3), 93-99. https://doi.org/10.32479/irmm.6920

Roznowski, M., \& Hulin, C. (1992). The scientific merit of valid measures of general constructs with special reference to job satisfaction and job withdrawal. In C. J. Cranny, P. C. Smith, \& E. F. Stone (Eds.), Job satisfaction (pp. 123-163). Lexington.

Sarıköse, S., \& Göktepe, N. (2021). Effects of nurses' individual, professional and work environment characteristics on job performance. Journal of Clinical Nursing, 15921. https://doi.org/10.1111/jocn.15921

Scarpello, V., \& Campbell, J. P. (1983). Job satisfaction: Are all the parts there? Personnel Psychology, 36, 577-600. https://doi.org/10.1111/j.1744-6570.1983.tb02236.x

Sert, S. (2017). Otel işletmelerinde çalışan işgörenlerin iş özellikleri ve örgütsel yapı algılarının yabancılaşma düzeylerine etkisi [Ph. D. Thesis]. Gazi University.

Shafique, I., N. Kalyar, M., \& Ahmad, B. (2018). The nexus of ethical leadership, job performance, and turnover intention: The mediating role of job satisfaction. Interdisciplinary Description of Complex Systems, 16(1), 71-87. https://doi.org/10.7906/indecs.16.1.5

Shrout, P. E., \& Bolger, N. (2002). Mediation in experimental and nonexperimental studies: New procedures and recommendations. Psychological Methods, 7(4), 422-445. https://doi.org/10.1037/1082-989X.7.4.422

Sigler, T. H., \& Pearson, C. M. (2000). Creating an empowering culture: Examining the relationship between organizational culture and perceptions of empowerment. Journal of Quality Management, 5, 27-52. https://doi.org/10.1016/S1084-8568(00)00011-0

Simamora, H. (1997). Manajemen Sumber Daya Manusia, Edisi ke-2, Cetakan ke-1. Yogyakarta: STIE YKPN.

Sims, H. P., Szilagyi, A. D., \& Keller, R. T. (1976). The measurement of job characteristics. Academy of Management Journal, 19(2), 195-212. https://doi.org/10.2307/255772

Singh, J. (1998). Striking a Balance in Boundary-Spanning Positions: An Investigation of Some Unconventional Influences of Role Stressors and Job Characteristics on Job Outcomes of Salespeople. Journal of Marketing, 62(3), 19. https://doi.org/10.1177/002224299806200305 
Job Characteristics' Causal Effects on Individual Job Performance Perceptions...

Soper, D. (2021). A-priori Sample Size Calculator for Structural Equation Models. https://www.danielsoper.com/statcalc/calculator.aspx?id=89

Taber, T. D., \& Taylor, E. (1990). A review and evaluation of the psychometric properties of the job diagnostic survey. Personnel Psychology, 43(3), 467-500.

https://doi.org/10.1111/i.1744-6570.1990.tb02393.x

Topcu, M. K., Beğenirbaş, M., \& Turgut, E. (2017). Örgütsel Sinizm, Zorunlu Örgütsel Vatandaşlık Davranışları ve İş Tatmininin Bireysel İş Performansına Etkilerinin Belirlenmesine Yönelik İmalat Sanayide Bir Uygulama. Yönetim ve Ekonomi: Celal Bayar Üniversitesi Iktisadi ve Idari Bilimler Fakültesi Dergisi, 24(2), 502-522. https://doi.org/10.18657/vonveek.335261

Trépanier, S. G., Forest, J., Fernet, C., \& Austin, S. (2015). On the psychological and motivational processes linking job characteristics to employee functioning: Insights from selfdetermination theory. Work and Stress, 29(3), 1-20. https://doi.org/10.1080/02678373.2015.1074957.

Tyagi, P. K. (1985). Relative Importance of Key Job Dimensions and Leadership Behaviors in Motivating Salesperson Work Performance. Journal of Marketing, 49(3), 76. https://doi.org/10.2307/1251617

Van den berg, P. T., \& Feij, J. A. (2003). Complex relationships among personality traits, job characteristics, and work behaviors. International Journal of Selection and Assessment, 11(4), 326-339. https://doi.org/10.1111/j.0965-075X.2003.00255.x

Van Dyne, L., \& LePine, J. A. (1998). Helping and voice extra-role behaviors: Evidence of construct and predictive validity. Academy of Management Journal, 41(1), 108-119. https://doi.org/10.2307/256902

Viswesvaran, C. (2002). Assessment of individual job performance: A review of the past century and a look ahead. In Handbook of Industrial, Work and Organizational Psychology,

Volume 1: Personnel Psychology. (pp. 110-126). Sage Publications Ltd. https://doi.org/10.4135/9781848608320.n7

Viswesvaran, C., \& Ones, D. S. (2000). Perspectives on models of job performance. International Journal of Selection and Assessment, 8(4), 216-226. https://doi.org/10.1111/1468-2389.00151

Viswesvaran, C., Schmidt, F. L., \& Ones, D. S. (2002). The moderating influence of job performance dimensions on convergence of supervisory and peer ratings of job performance: Unconfounding construct-level convergence and rating difficulty. Journal of Applied Psychology, 87(2), 345-354. https://doi.org/10.1037/0021-9010.87.2.345

Wegman, L. A., Hoffman, B. J., Carter, N. T., Twenge, J. M., \& Guenole, N. (2018). Placing job characteristics in context: Cross-temporal meta-analysis of changes in job characteristics since 1975. Journal of Management, 44(1), 352-386. https://doi.org/10.1177/0149206316654545

Weiss, D. J., Dawis, R. V., England, G. W., \& Lofquist, L. H. (1967). Manual for the Minnesota satisfaction questionnaire (Minnesota studies in vocational rehabilitation, No. 22). Industrial Relations Center, Minneapolis: University of Minnesota.

West, S., Finch, J., \& Curran, P. (1995). Structural equation models with non-normal variables: Problems and remedies. In R. H. Hoyle (Ed.), Structural equation modelling: Concepts, Issues and Applications (pp. 56-75). Sage. 
Westland, J. (2010). Lower bounds on sample size in structural equation modeling. Electronic $\begin{array}{llll}\text { Commerce Research \& Applications, 9(6), 476-487. } & \text {. }\end{array}$ https://doi.org/10.1016/i.elerap.2010.07.003

Williams, L. J., \& Anderson, S. E. (1991). Job satisfaction and organizational commitment as predictors of organizational citizenship behavior and in-role behaviors. Journal of Management, 17(1), 601-617. https://doi.org/10.1177/014920639101700305

Yaldızbaş, S. (2015). Karizmatik liderlik davranışlarının iş performansına etkisinde iş tatmininin aracılık rolü [Ph. D. Thesis]. Süleyman Demirel University.

Yustina, A. I., \& Valerina, T. (2018). Does work-family conflict affect auditor's performance? Examining the mediating roles of emotional exhaustion and job satisfaction. Gadjah Mada International Journal of Business, 20(1), 89-111. https://doi.org/10.22146/gamaijb.26302 